\title{
Sponge community (Porifera) in coral reef ecosystem in Sabang, Aceh Province, Indonesia
}

\author{
ELSA DIANITA AULIA", TRI ARYONO HADI" ${ }^{\nu »,}$ RIZKIE SATRIYA UTAMA \\ Research Center for Oceanography, Indonesian Institute of Sciences. Jl. Pasir Putih Raya No.1, Ancol Timur, Pademangan, North Jakarta 14430, Jakarta, \\ Indonesia. Tel./fax.: +62-21-64713850, •email: elsadianitaa@gmail.com; •`ari_080885@yahoo.com
}

Manuscript received: 9 February 2021. Revision accepted: 27 May 2021.

\begin{abstract}
Aulia ED, Hadi TA, Utama RS. 2021. Sponge community (Porifera) in coral reef ecosystem in Sabang, Aceh Province, Indonesia. Biodiversitas 22: 3394-3402. Sponges are one of the most influential benthic organisms in coral reef ecosystems. Many studies about sponge communities have been carried out globally, from tropical to temperate regions. In Indonesia, however, sponge communities have not been adequately observed, especially their diversity and interaction with habitats. Sabang, a developing city located in the northwest of Indonesia, has a lack of information about benthic communities and no reports about sponges. This study investigated the sponge community (species richness, coverage, and morphological characters) and the interactions, both within sponges and with corals and substrates, in Sabang. The study found that the sponge richness (species and morphology) and coverage are categorized as poor, having only 24 species with seven morphologies, and coverage of $1.79 \pm 1.03 \%$ (SE). The interaction analyses showed significant relationships occur among sponge variables but not between sponges and corals, nor between sponges and their substrates. These results could be attributed to the hydrodynamic-related stresses in Sabang, which are likely influenced by exposure to the open ocean, a condition that is less favorable to diversity and interaction. It is necessary to regularly monitor the condition of benthic communities in Sabang in order to better understand their stable state and detect any change over time.
\end{abstract}

Keywords: Coral reef, diversity, interaction, Sabang, sponges

\section{INTRODUCTION}

Coral reefs have been recognized as the most diverse ecosystem on earth. Indonesian coral reefs are one of the biodiversity hotspots as they are part of the coral triangle region (Hoeksema 2007). However, their biodiversity gradually declines as one moves away from the center of the triangle, into more peripheral areas (De Voogd 2005). Unfortunately, the census of coral reef benthic communities in Indonesia is far from adequate, impeding future research and its application.

Sponges play essential roles in coral reef ecosystems. Previous studies have shown that sponges play a crucial role in nutrient cycling (Pile and Young 2006; de Goeij et al. 2017), microbial association (Selvin et al. 2010; Yang et al. 2011), as well as any related substrate modification (Schönberg 2008; Biggs 2013). For example, sponges can bind rubble into a larger and more stable form and be significantly more likely to be consolidated over time than rubble alone. However, sponges are also known as competitors among benthic communities. Sponges compete with corals for space to grow; when sponges are abundant, the stable state of coral-dominated reefs may be compromised. In this situation, sponges can kill corals by overgrowing their colonies, and by hindering coral recruitment as a result of occupying potential recruitment space (González-Rivero et al. 2011; Turicchia et al. 2018; Brandt et al. 2019). Considering these issues, it is necessary in poorly studied areas, to develop an understanding of the interaction between sponges and corals, as well as with their substrates.

Research on Indonesian sponges is relatively limited. Sponges tend to be neglected in many surveys because of difficulties in taxa identification (de Voogd et al. 2009). Previous studies were mostly carried out in the eastern part of Indonesia as it is part of the coral triangle region, wellknown as the world's richest zone of marine biodiversity. The triangle includes such areas as the Spermonde Archipelago, Sulawesi (de Voogd et al. 2006); North Sulawesi (Calcinai et al. 2017); Derawan Islands, Kalimantan (de Voogd et al. 2009); and Wakatobi Marine National Park (Bell and Smith 2004; Powell et al. 2010). On the other hand, in the western part of Indonesia, the sponge community is still poorly studied (Setiawan et al. 2019).

Coral reefs in Sabang, in the northwestern province of Aceh experienced bleaching events in 2010 and 2016 that caused coral cover to decline dramatically (Tun et al. 2010; Octavina et al. 2018). However, information regarding sponges in Sabang was overlooked at that time, resulting in incomplete studies of the benthic communities. Apart from such bleaching events, Sabang also has a unique environment as it directly faces the open ocean, characterized by strong currents and waves. Consequently, only certain types and characteristics of sessile benthos are likely to survive. There is no report yet about the sponge community in Sabang. This study aimed to investigate the sponge community structure (species richness, coverage, and morphological characters) in Sabang, the relationships among these sponge variables, as well as the interactions of 
the sponges with corals, and of sponges with substrates.

\section{MATERIALS AND METHODS}

\section{Study area}

The study was carried out in March 2017 in Sabang, Aceh province, Indonesia by taking observations at 10 stations, mostly located in the north due to safety considerations (Figure 1). The stations spanned from the west to the east along Sabang bay and its other small islands, including Rubiah Island (St 1 and St 3), Seulako Island (St 2), and Klah Island (St 8).

\section{Procedures}

Sponge diversity

Sponge diversity in Sabang was observed by using a belt transect method (Eleftheriou and McIntyre 2005) with a modified size of $70 \times 2$ meters - installed parallel to the coastline at a depth of around 5 meters. Each transect was placed at each station. Sponges found along the transect were recorded (species and morphologies), but small cryptic and encrusting sponges less than $5 \mathrm{~cm}$ in diameter were excluded from this study. Sponges that could not be identified on-site at the time had a section about $10 \mathrm{~cm}^{2}$ cut off for identification later in the laboratory. For the classification of sponge morphology the main reference used was Cheng et al. (2008), whereas for species identification the main reference was Van Soest and Hooper (2002), reaffirmed by referring to Van Soest et al. (2021) for updated names.

\section{Benthic and substrate covers}

A photo-quadrat transect was used to estimate the percent cover of benthos (sponges and corals) and substrates. A 44 x $58 \mathrm{~cm}$ iron frame was installed along a transect line (the same line as belt transect), within an interval between quadrats of 1 meter (Giyanto et al. 2010). It is claimed that this size of the iron frame is relatively accurate for representing benthic communities and is practical to use; the observer does not need to be a longdistance from the frame to take a photo, resulting in the photos that have good enough quality to enable identification (Giyanto et al. 2010).

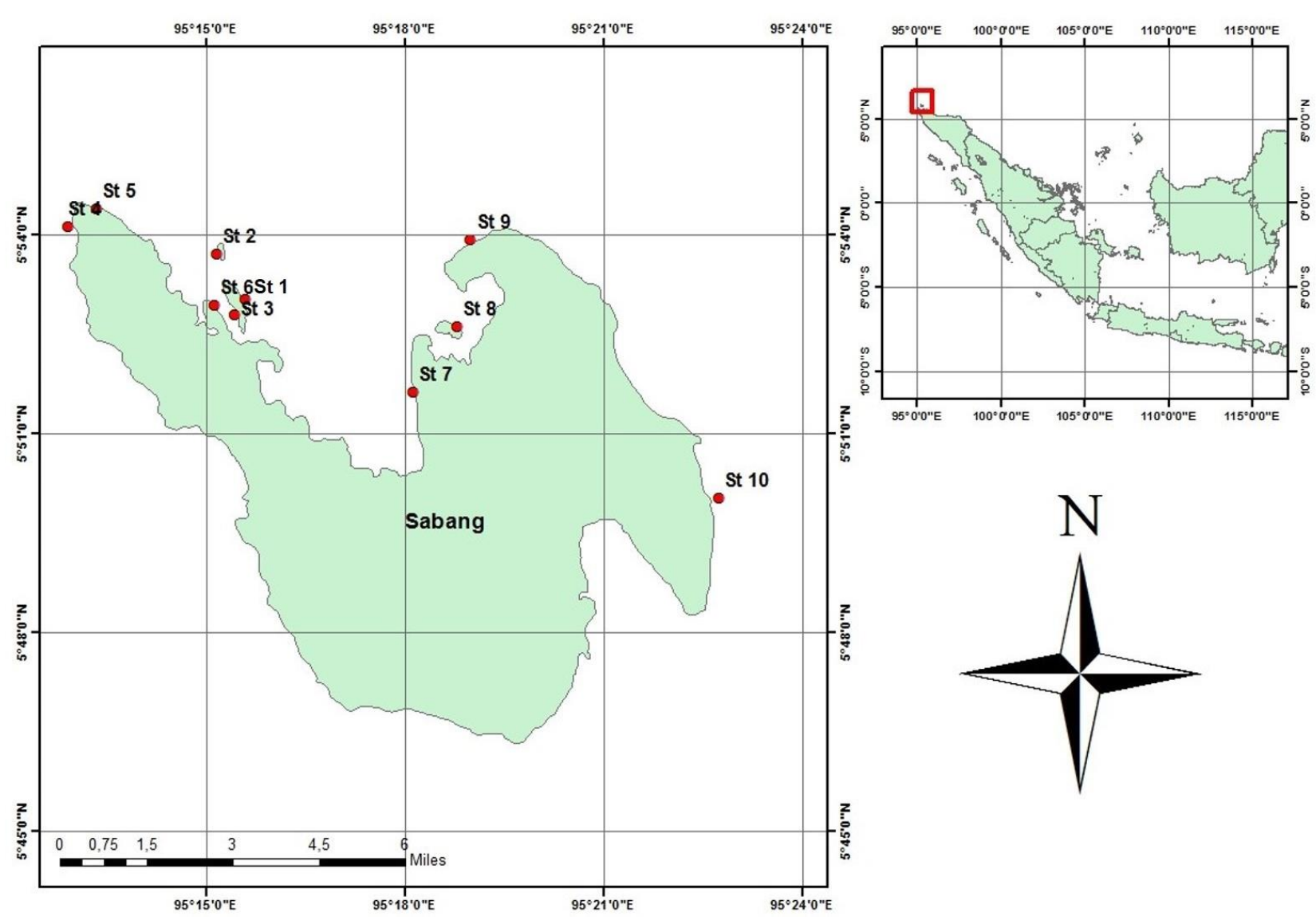

Figure 1. Location of the study area on the north side of Sabang, Aceh Province, Indonesia. Red circles indicate the observation station at Weh Island (St 4, St 5, St 6, St 7, St 9, St 10), Rubiah Island (St 1 and St 3), Seulako Island (St 2) and Klah Island (St 8) 


\section{Data analysis}

Photos along the quadrat transect were analyzed using CPCe software (Kohler and Gill 2006) used for determining benthic and substrate cover. Furthermore, the percentage cover of benthic and substrate category is calculated for each photo data. categorization of benthos and substrates referred to Giyanto et al. (2017). The percentage data from each transect at each station was then averaged as benthic cover data for each station. The interrelationship between sponge variables (number of species, coverage, and morphology) and the relationship between sponges and corals as well as substrates from each station were examined using linear regression analyses. The significance of the relationships was tested by Spearman's rank correlation, due to non-normal data distribution, using IBM SPSS statistic 25 software (Beazley et al. 2013).

\section{RESULTS AND DISCUSSION}

\section{Sponge richness and morphology}

Overall, there were 24 sponge species from eight orders recorded during the study. The most common orders were Haplosclerida, Dictyoceratida, and Poecilosclerida, having 11,5 , and 3 species respectively. Meanwhile, the rest orders had one species for each (Table 1).

In terms of species distribution, Hyrtios sp. and Xestopsongia vansoesti were the most common sponges found in Sabang, encountered at 5 and 4 of 10 stations respectively. On the other hand, 12 sponges were distributed at one location only, especially for Axinellida, Bubarida, Scopalinida, and several of the Haplosclerida sponges, Dysidea sp., Coelocarteria singaporensis and Clathria (Microciona) sp. (red).

This study identified seven morphological characteristics from the sponges recorded. In general, sponges with wide basal areas appear to be dominant in Sabang, given that the massive form was the most favored morphology, accounting for $41.6 \%$ of all of the sponges, followed by the encrusting form (in 29.17\%), with the other forms representing less than 10\% (Figure 2).

Table 1. List of sponge species found at Sabang, Aceh Province, Indonesia

\begin{tabular}{|c|c|c|c|c|c|c|c|c|c|c|c|}
\hline Ordo/species & Morphology & St 1 & St 2 & St 3 & St 4 & St 5 & St 6 & St 7 & St 8 & St 9 & St 10 \\
\hline \multicolumn{12}{|l|}{ Axinellida } \\
\hline Dragmacidon $\mathrm{sp}$. & $\mathrm{Ma}$ & & + & & & & & & & & \\
\hline \multicolumn{12}{|l|}{ Bubarida } \\
\hline Acanthella cavernosa & $\mathrm{Ma}$ & & & & & & & + & & & \\
\hline \multicolumn{12}{|l|}{ Dictyoceratida } \\
\hline Phyllospongia foliascens & Fo & + & & & & + & & & & & + \\
\hline Dysidea sp. & $\mathrm{Ma}$ & & & + & & & & & & & \\
\hline Dactylospongia elegans & En & & & & + & & & & & & + \\
\hline Hyrtios sp. & $\mathrm{Ma}$ & & & + & & & & + & + & + & + \\
\hline Lamellodysidea herbacea & En & & & & + & + & & & & & + \\
\hline \multicolumn{12}{|l|}{ Haplosclerida } \\
\hline Acanthostrongylophora ingens & $\mathrm{Ma}$ & + & & & + & + & & & & & \\
\hline Amphimedon sp. & $\mathrm{Br}$ & & & + & & & & + & & & + \\
\hline Amphimedon paraviridis & $\mathrm{Ma}$ & & & + & & + & & + & & & \\
\hline Callyspongia sp. & Cup & & & & & + & & & & & \\
\hline Haliclona sp. (green) & En & & & & & & & & + & & \\
\hline Petrosia sp. & $\mathrm{Ma}$ & & & & + & & & & & & \\
\hline Petrosia corticata & $\mathrm{Ma}$ & & & & & & & & & & + \\
\hline Niphates olemda & $\mathrm{Tu}$ & & & & & + & & & & & \\
\hline Xestospongia testudinaria & Cup & + & & & + & & & & & & \\
\hline Xestospongia vansoesti & En & & + & & + & & & + & + & & \\
\hline Xestospongia sp. & $\mathrm{Ma}$ & & & & & & + & & & & \\
\hline \multicolumn{12}{|l|}{ Peocilosclerida } \\
\hline Coelocarteria singaporensis & Bur & & & & & & & & & & + \\
\hline Clathria (Microciona) sp. (green) & En & & & + & & & & & & & + \\
\hline Clathria (Microciona) sp. (red) & En & & & + & & & & & & & \\
\hline \multicolumn{12}{|l|}{ Scopalinida } \\
\hline Stylissa massa & Fol & + & & & & & & & & & \\
\hline \multicolumn{12}{|l|}{ Tetractinellida } \\
\hline Theonella sp. & $\mathrm{Ma}$ & & & & + & + & & & & & \\
\hline \multicolumn{12}{|l|}{ Verongiida } \\
\hline Pseudoceratina purpurea & En & + & & & & + & & & & & + \\
\hline Total & & 5 & 2 & 6 & 7 & 8 & 1 & 5 & 3 & 1 & 9 \\
\hline
\end{tabular}

Note: Fo: foliose; Ma: massive; En: encrusting; Br: branching; Bu: burrowing; Tu: tubular; Cup: cup 


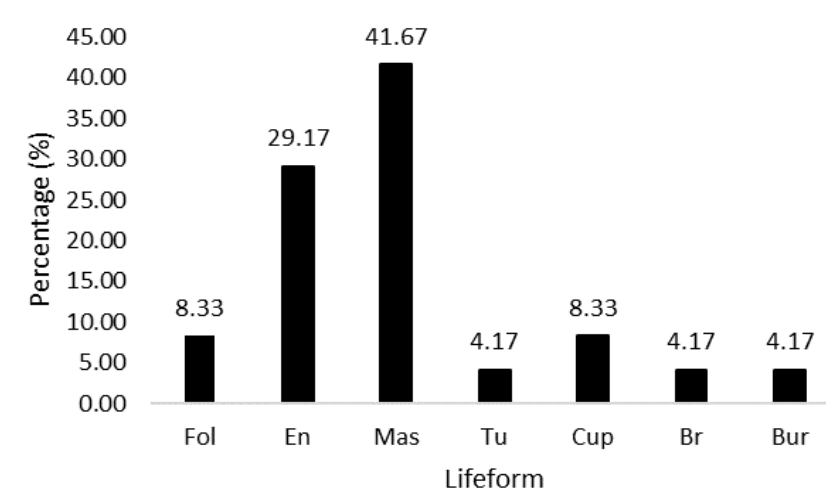

Figure 2. The percentage of sponge morphology in Sabang, Aceh Province, Indonesia. (Fo: foliose; Ma: massive; En: encrusting; Br: branching; Bu: burrowing; Tu: tubular; Cup: cup)

The analysis shows that there was a significant positive relationship between the number of sponge species recorded from the belt transect and the sponge covers resulting from the photo quadrat transect $(P=0.04$, Figure 3.A). Furthermore, the number of sponge species was also correlated significantly with the number of lifeforms $(P=$ 0.00 , Figure 3.B). In other words, any difference in the number of species among the stations affected considerably the sponge covers and the number of lifeforms.

\section{Sponge community in coral reef}

Based on the percent cover of benthic categories (Table 2 ), the average sponge cover in Sabang was $1.79 \pm 1.03 \%$ (SE). The sponge cover was lower than the cover for the other benthic categories, including corals and another biota. The linear regression suggests that there was a negative relationship between sponge cover and coral cover although the analysis of variance indicates an insignificant result, $P=0.722$ (Figure 4.A). This relationship, if confirmed, means that sponge cover decreases with increase in coral cover. Similarly, a rise in coral cover could lead to a decrease in the number of sponge species (Figure 4.B). However, increasing number of coral species did not appear to significantly affect the number of sponge species (Figure 5).

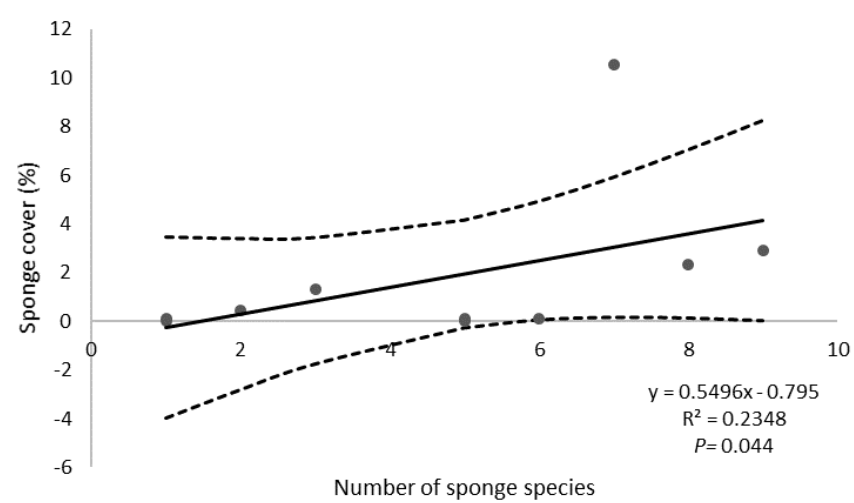

A

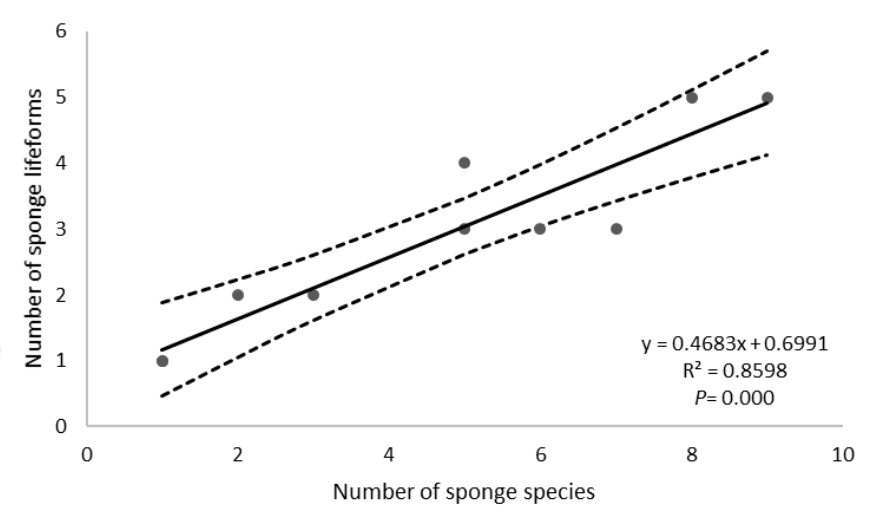

B

Figure 3. Relationship between: A. the number of sponge species and coverage of sponge, B. the number of sponge species and the number of sponge lifeforms; using Spearman correlation. Figures 3.A and 3.B showed a significant correlation $(\mathrm{P}<0.05)$. Scatter plot showing the fitted linear regression line. Circles represent the data from each station, black lines show the fitted linear regression line, and dotted lines indicate the $95 \%$ confidence interval

Table 2. The percent cover of benthic categories at each station determined from the photo quadrat transect

\begin{tabular}{|c|c|c|c|c|c|c|c|c|c|c|c|}
\hline Benthic category & St.1 & St. 2 & St. 3 & St. 4 & St. 5 & St. 6 & St. 7 & St. 8 & St. 9 & St. 10 & Average \\
\hline Coral (HC) & 10.00 & 57.33 & 26.67 & 12.00 & 29.78 & 34.56 & 18.22 & 55.89 & 26.44 & 13.89 & 28.48 \\
\hline Dead Coral (DC) & 0.00 & 0.00 & 0.00 & 0.11 & 0.00 & 0.00 & 0.11 & 0.00 & 0.00 & 0.00 & 0.02 \\
\hline Dead Coral with Algae (DCA) & 11.11 & 33.78 & 15.56 & 3.56 & 39.89 & 61.44 & 31.22 & 21.44 & 56.78 & 55.67 & 33.04 \\
\hline Soft Coral (SC) & 0.00 & 0.00 & 0.00 & 0.00 & 0.00 & 0.00 & 0.00 & 0.00 & 0.11 & 0.11 & 0.02 \\
\hline Sponge (SP) & 0.11 & 0.44 & 0.11 & 10.56 & 2.33 & 0.00 & 0.00 & 1.33 & 0.11 & 2.89 & 1.79 \\
\hline Fleshy Seaweed (FS) & 1.22 & 0.00 & 0.00 & 0.11 & 0.89 & 0.00 & 0.00 & 0.22 & 0.22 & 0.56 & 0.32 \\
\hline Other Biota (OT) & 1.78 & 7.67 & 1.00 & 72.44 & 12.78 & 2.89 & 1.00 & 1.33 & 2.11 & 1.89 & 10.49 \\
\hline Rubble (R) & 1.22 & 0.33 & 6.67 & 0.00 & 3.44 & 0.56 & 13.89 & 3.22 & 0.56 & 12.11 & 4.20 \\
\hline Sand (S) & 49.33 & 0.44 & 47.89 & 0.00 & 10.89 & 0.56 & 5.33 & 16.56 & 13.67 & 12.89 & 15.76 \\
\hline Silt (SI) & 0.00 & 0.00 & 0.00 & 0.00 & 0.00 & 0.00 & 30.22 & 0.00 & 0.00 & 0.00 & 3.02 \\
\hline Rock (RK) & 25.22 & 0.00 & 2.11 & 1.22 & 0.00 & 0.00 & 0.00 & 0.00 & 0.00 & 0.00 & 2.86 \\
\hline
\end{tabular}




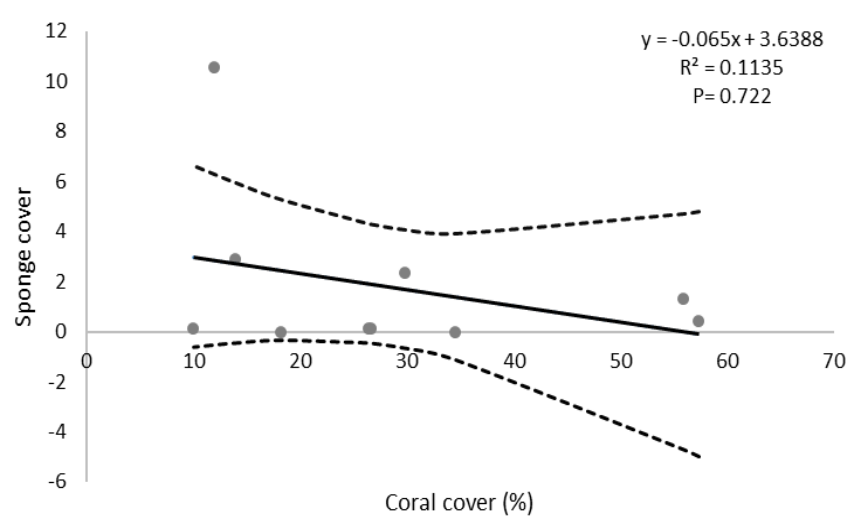

A

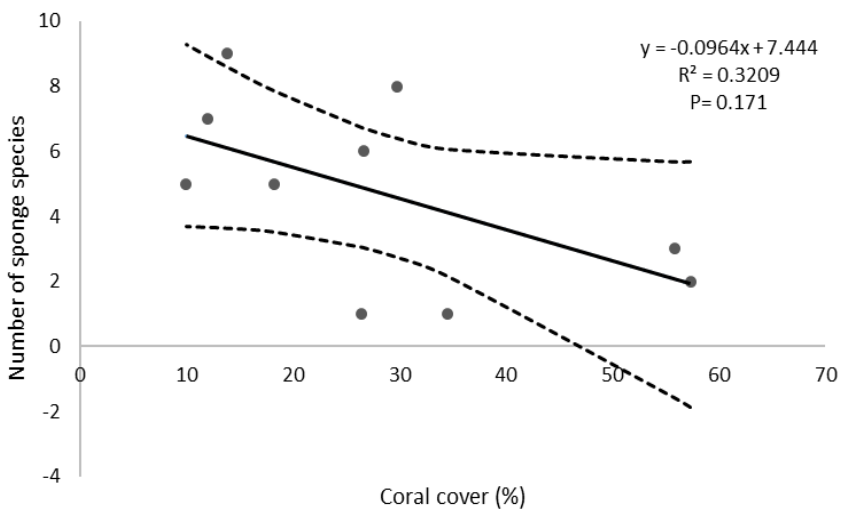

B

Figure 4. Relationship between: A. sponge cover vs coral cover, B. the number of sponge species vs coral cover. Scatter plot showing the fitted linear regression line. Circles represent the data from each station, black lines show the fitted linear regression line, and dotted lines indicate the $95 \%$ confidence interval

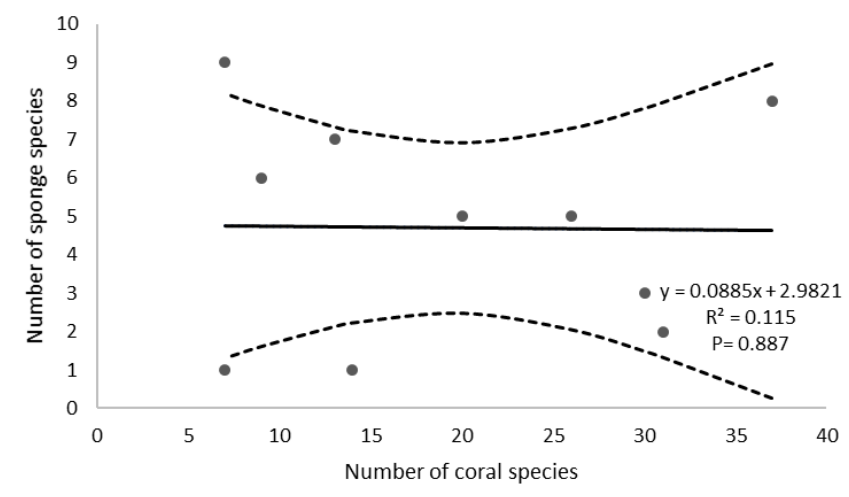

Figure 5. Relationship between the number of sponge and coral species. Scatter plot showing the fitted linear regression line. Circles represent the data from each station, black lines show the fitted linear regression line, and dotted lines indicate the $95 \%$ confidence interval

In this study, we categorize substrate types into a stable substrate, consisting of dead coral with algae (DCA) and rocks $(\mathrm{R})$; then an unstable substrate consisting of rubble $(\mathrm{Rb})$ and sand $(\mathrm{S})$. In general, the correlation between sponges (the number of species and lifeforms) and the substrate types does not show any significant relationships (Figure 6).

\section{Discussion}

Based on the results, the number of sponge species in Sabang is much smaller than recorded in other studies conducted in the middle and eastern part of Indonesia; i.e., 118 species in the Thousand Island (de Voogd and Cleary 2008); 100 species in Wakatobi (Bell and Smith 2004); and 168 species in Derawan Island by (de Voogd et al. 2009). However, the number is relatively similar to a previous study in Simeuleu, which is also part of Aceh Province, in which there were 18 species identified (Setiawan et al. 2019). A possible reason for this result is related to food availability. A previous study carried out in Sabang claimed that the water condition is oligotrophic, i.e., having a little amount of chlorophyll $a$ concentration (Agustina et al. 2017). In this case, a low concentration of chlorophyll $a$ may result in low sponge cover because the sponges lack adequate food to supply their energy needs (Leinfelder et al. 2012). Another possible reason is associated with the hydrodynamic regime. Sabang is located in the northwest of Indonesia and facing directly towards the Indian Ocean, and is subject to more hydrodynamic stress than the eastern part of Indonesia (Habibie et al. 2013). The hydrodynamic stress may limit the colonization and growth of sponges by affecting substrate stability, turbidity, and turbulence (Wilkinson and Evans 1989; Vinod et al. 2014).

The most common sponges recorded, 11 of 24 species, belong to Haplosclerida, which contains approximately 1341 valid species globally (Van Soest et al. 2012). This dominance is related to the habitat preference of the sponges, which is commonly shallow water reefs (Van Soest and Hooper 2002). Xestospongia vansoesti was the most common sponge from this order, distributed at four stations, while Hyrtios sp., distributed at five stations, belongs to Dyctioceratida. These sponges are very common in the Indo-West Pacific (Van Soest and Hooper 2002). In addition to the number of orders, a previous taxonomic revision has disused particular orders and established new orders which were previously classified as families (Morrow and Cardenas 2015). In this case, a disused order of Haliclondrida has resulted in three new orders (Axinellida, Bubarida, and Scopalinida), making the number of orders recorded higher but fewer species for each of the new orders.

In terms of morphologies, massive and encrusting sponges were very dominant, contributing approximately $70 \%$ of sponge morphologies identified in Sabang. Previous studies conducted in Indonesia also indicate that sponges with large basal areas (massive and encrusting) are very dominant in particular areas, such as the south coast of Java (Hadi et al. 2018), Seribu Islands (de Voogd and Cleary 2008; Utami et al. 2018), and Bengkulu (Utami et 
al. 2018). These morphologies enable sponges to have a good grip to withstand strong currents (Bell and Barnes 2000; Wulff 2010). In addition, they are also less likely to fracture than other forms such as branching or tubular types (Bell and Barnes 2000). In this case, depending on the type of skeleton, species with a relatively high proportion of spicules such as $M$. ramulosa and $H$. caerulea may be more fragile than those contain spongins because they are less flexible (Wulff 1995; Ávila and Carballo 2004; Vega 2002 in Ávila et al. 2011). Moreover, a study of biophysical factors on sponge morphologies suggests that increased wave height can change an upright sponge's shape to encrusting due to wave pressure (George et al. 2018). This study found that $X$. vansoest $i$ was almost encrusting rather than branching, enabling the sponge to have minimal friction against water current (Figure 7.A). Another sponge, $X$. testudiaria, also shows that the osculum is not rounded as usual but instead oval (Figure 7.B), adjusting to the direction of water current.

This study confirms that sponge cover is correlated significantly with sponge diversity. A previous study on corals also indicates that coral cover has a significant correlation with species richness (Komyakova et al. 2013). Moreover, declining coral cover by approximately $80 \%$ led to a $60 \%$ drop in coral species richness (Madin et al. 2018). Therefore, it can be assumed that sponge cover may be used as a proxy for sponge diversity; a decline in sponge cover can have a dire consequence on sponge diversity.

This study has also found that a significant correlation occurs between morphological diversity and species richness of sponges. In this case, particular sponges are still in their original shapes without being compromised by the hydrodynamic stress (Figure 8). Bell and Barnes (2001) confirm that sponge morphology can be used to estimate sponge diversity quantitatively. However, sponge morphology is rather complicated to define; although 25 to 27 specific types have been recognized (Boury-Esnault and Rutzler 1997; Hooper 2000) they are more usefully simplified into 12 types (Cheng et al. 2008). Due to the small number of sponge species in Sabang, using the simplified/common types of morphology is preferable. On the other hand, when it comes to high diversity regions, consisting of hundreds of species, detailed/specific types of morphology are more representative.

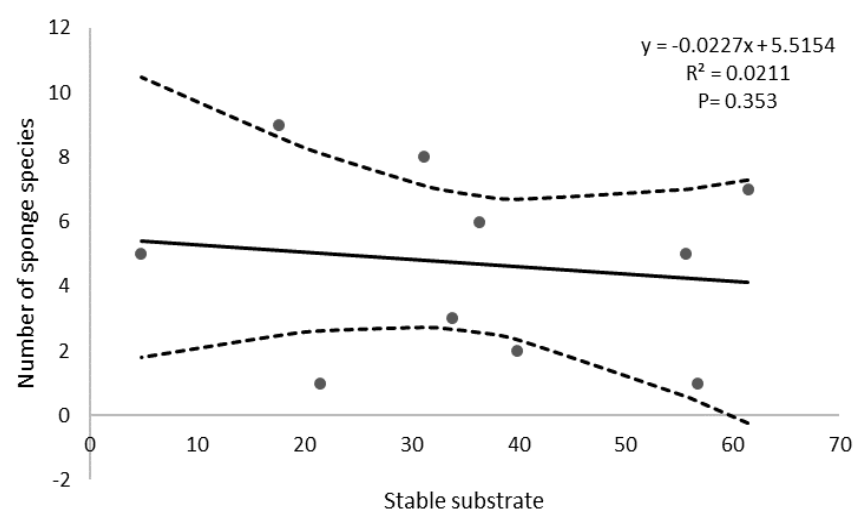

A

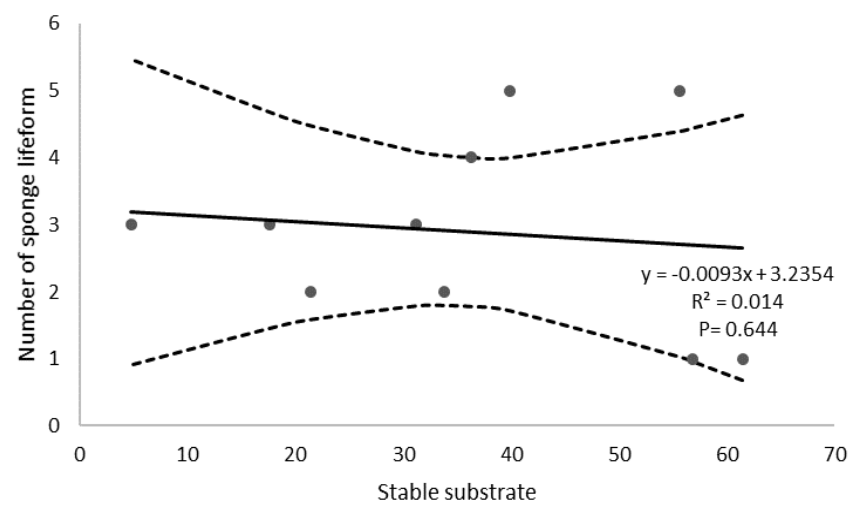

C

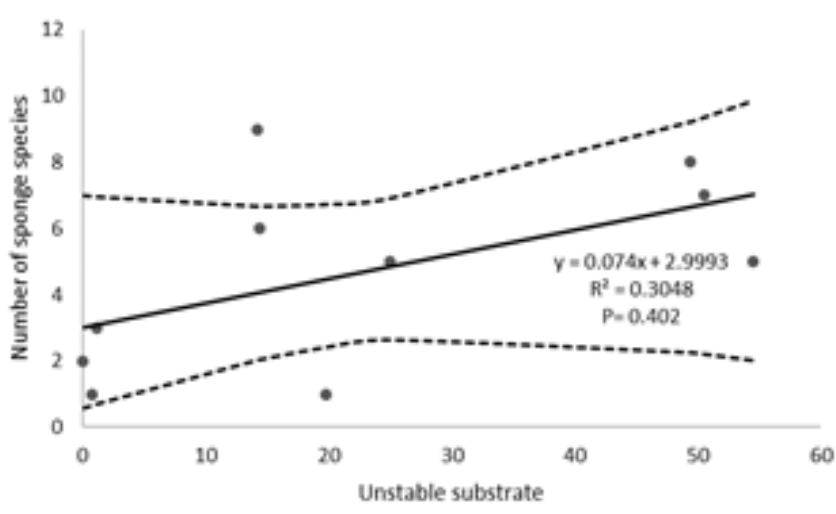

B

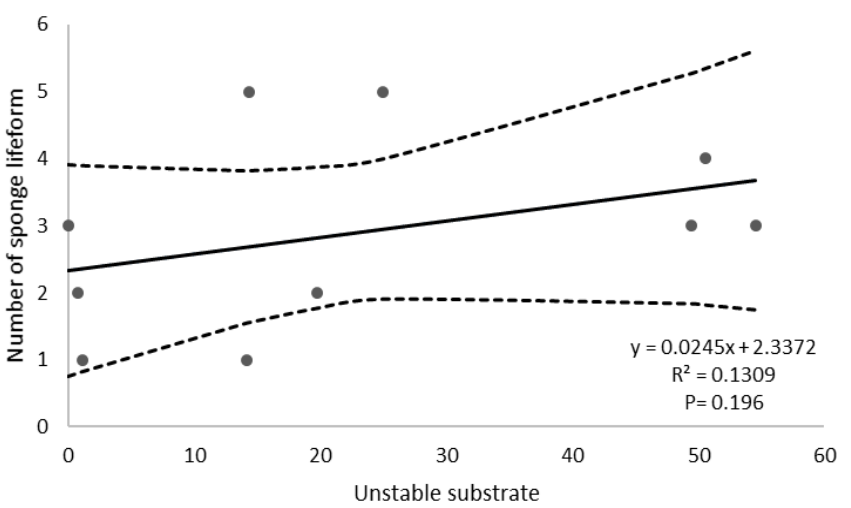

D

Figure 6. Relationship between the number of sponge species and: A. stable substrate cover, B. unstable substrate cover; and the number of sponge lifeforms and C. stable substrate cover, D. unstable substrate cover. Dotted lines indicate the $95 \%$ confidence interval 


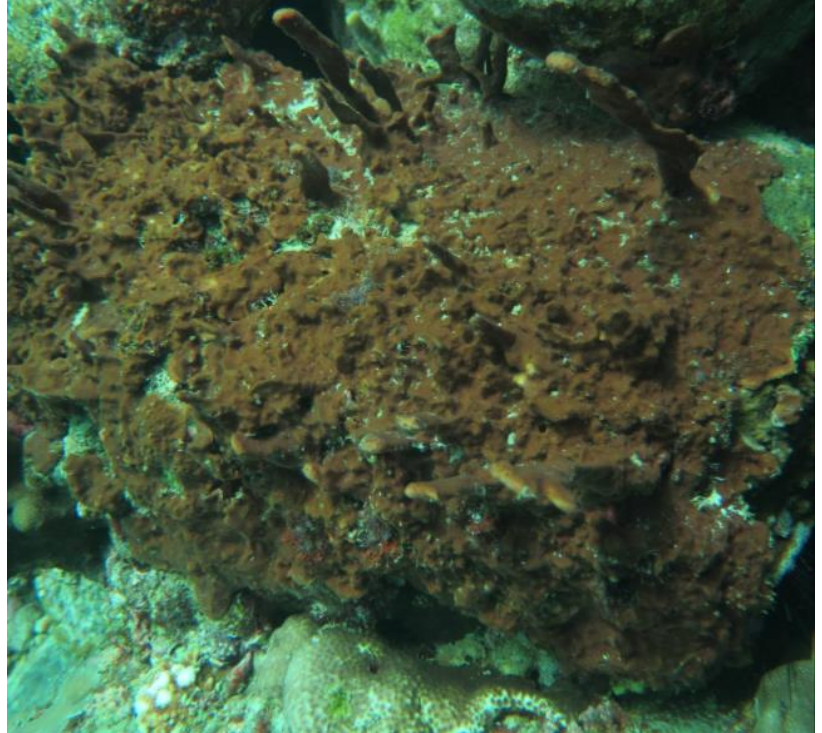

A

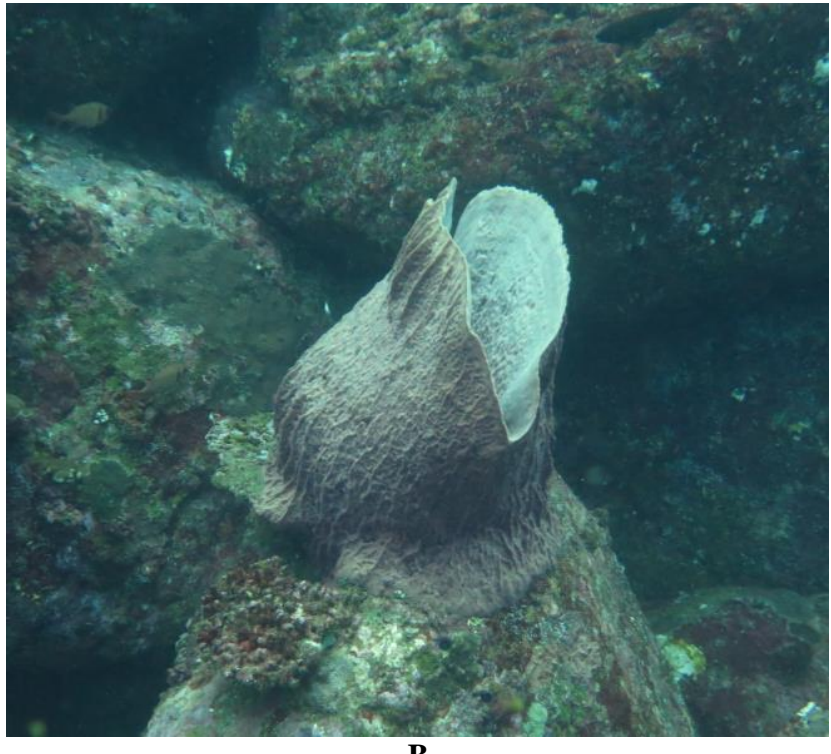

B

Figure 7. A. Xestospongia vansoesti with encrusting rather than branching morphology, B. X. testudinaria with oval osculum

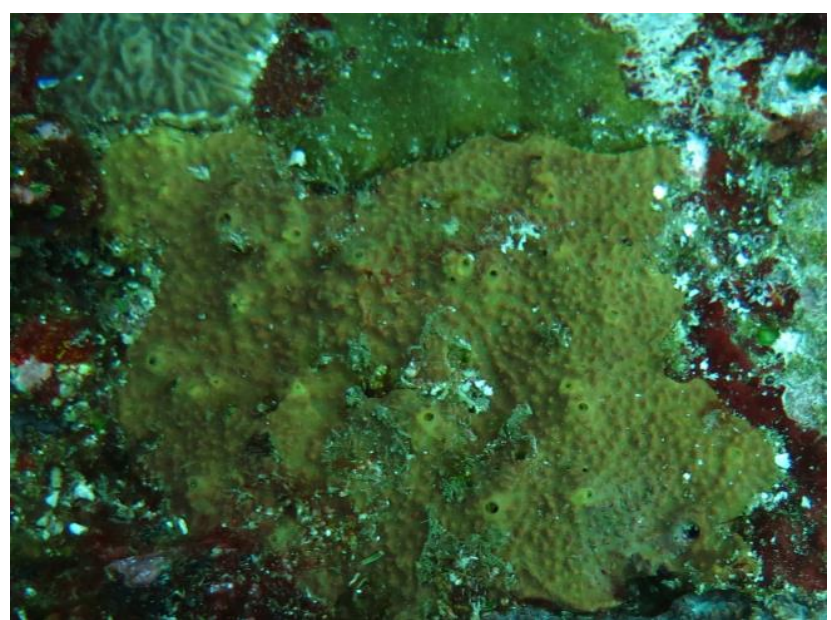

A

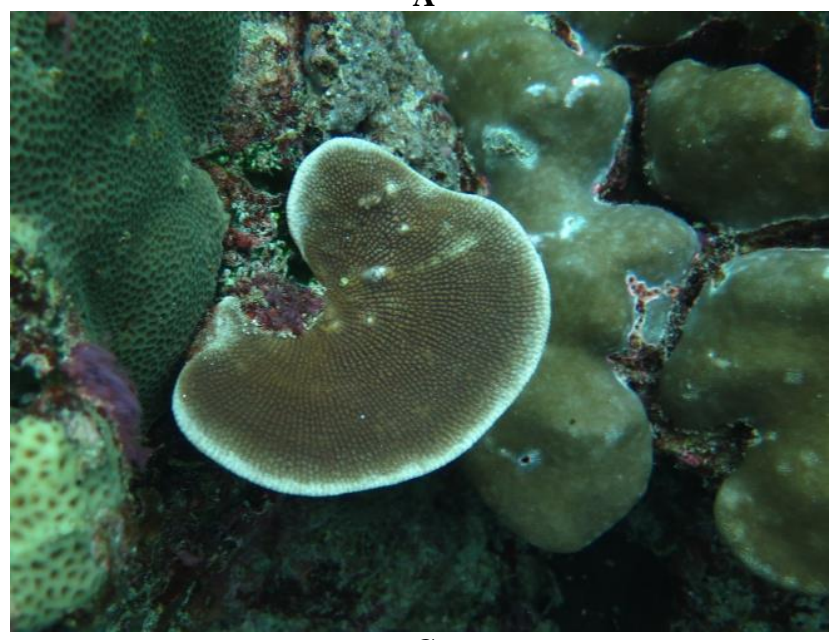

C

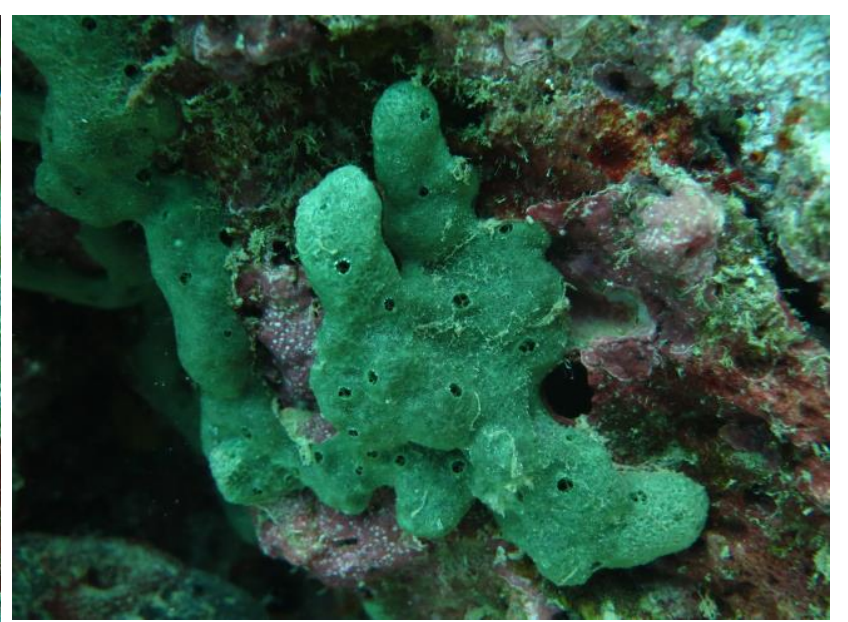

B

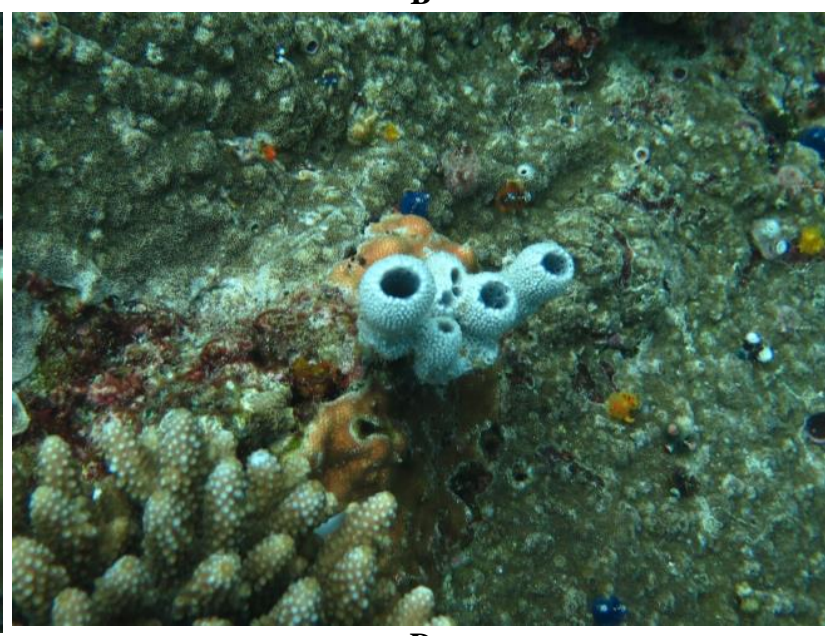

D

Figure 8. Sponges with their original morphologies in Sabang; A. Dactylospongia elegans, B. Amphimedon paraviridis, C. Carteriospongia foliascens, D. Niphates olemda 
Previous studies have claimed that sponges are the main competitors with corals in reef habitats, affecting the growth, recruitment, and mortality of corals (Chadwick and Morrow 2011; Chaves-Fonnegra and Zea 2011; Brandt et al. 2019). However, the result of this study indicates that the interaction between the sponge variables (cover and species richness) and corals was not statistically significant. From this study, it appears that competition may not occur in this part of Indonesian waters as recorded sponge cover was very low $(1.79 \pm 1.03 \%$ (SE)) compared to coral $(28.48 \pm 5.33 \%(\mathrm{SE}))$. Furthermore, the sponges recorded are not categorized as aggressive sponges (Aerts and Van Soest 1997). Thus, it is possible that predation is a factor that has constrained sponge cover. Spongivores on Caribbean reefs indirectly increased the reproductive potential of corals by reducing their loss of polyps to sponge overgrowth (Hill 1998). Apart from this, hydrodynamic stresses may indirectly affect the interaction between sponges and corals as well as the substrates as it can hamper growth rate and recruitment (Leichter and Witman 1997). In this case, competition for space, which usually occurs in healthy reefs, will not occur because many sponges and corals prefer surviving in a stressful hydrodynamic condition to competing with each other (Van Colen et al. 2010; Bell et al. 2013).

In conclusion, this study finds that sponge richness in Sabang is lower than is observed in other areas of Indonesia. Massive and encrusting forms dominate the sponge community in Sabang. Our result supports the hypothesis that there is a significant correlation between sponge richness and sponge cover, and between sponge richness and sponge lifeforms. However, the present study does not show a significant relationship between sponges and corals as well as the substrates. This information can help the management regime understand that sponge biodiversity can be used to predict the coverage as well as the life forms, and the specific interaction between sponges and corals needs to be monitored periodically to gain a better understanding of long-term interaction between these benthic communities.

\section{ACKNOWLEDGEMENTS}

The authors thank the Research Center for Oceanography and COREMAP-CTI, Jakarta, Indonesia for financial support and the local government agencies for the research permit. Special thanks go to deceased Prof. Pramudji who was the lead coordinator of this project in Sabang.

\section{REFERENCES}

Aerts LAM, Van Soest RWM. 1997. Quantification of sponge/coral interactions in a physically stressed reef community, NE Colombia. Mar Ecol Prog Ser 148: 125-134. DOI: 10.3354/meps148125.

Agustina S, Musman M, Ishaq, M. 2017. Status klorofil-a di Perairan Teluk Pria Laot Sabang, Provinsi Aceh. Depik 6 (3): 182-187. DOI: 10.13170/depik.6.3.8364. [Indonesian]
Ávila E, Carballo JL. 2004. Growth and standing stock biomass of a mutualistic association between the sponge Haliclona caerulea and the red algae Jania adherens. Symbiosis 36: 225-244.

Ávila E, Carballo JL, Vega C, Camacho L, Barrón-Álvarez JJ, PadillaVerdín C, Yáñez-Chávez B. 2011. Deposition of shallow water sponges in response to seasonal changes. J Sea Res 66 (2): 172-180. DOI: $10.1016 /$ j.seares.2011.06.001.

Beazley LI, Kenchington EL, Murillo FJ, Sacau MDM. 2013. Deep-sea sponge grounds enhance diversity and abundance of epibenthic megafauna in the Northwest Atlantic. ICES J Mar Sci 70 (7): 14711490. DOI: 10.1093/icesjms/fst124.

Bell JJ, Barnes DK. 2000. A sponge diversity centre within a marine 'island'. In: Jones MB, Azevedo JMN, Neto AI, Costa AC, Martins AMF (eds). Island, Ocean and Deep-Sea Biology. Springer, Dordrecht.

Bell JJ, Barnes DK. 2001. Sponge morphological diversity: A qualitative predictor of species diversity? Aquatic Conserv: Mar Fresh Ecosyst 11 (2): 109-121. DOI: $10.1002 / \mathrm{aqc} .436$.

Bell JJ, Smith D. 2004. Ecology of sponge assemblages (Porifera) in the Wakatobi region, south-east Sulawesi, Indonesia: richness and abundance. J Mar Biol Assoc U K84 (3): 581-591. DOI: $10.1017 / \mathrm{s} 0025315404009580 \mathrm{~h}$.

Bell JJ, Davy SK, Jones T, Taylor MW, Webster NS. 2013. Could some coral reefs become sponge reefs as our climate changes? Glob Chang Biol 19 (9): 2613-2624. DOI: 10.1111/gcb.12212.

Biggs BC. 2013. Harnessing natural recovery processes to improve restoration outcomes: an experimental assessment of sponge-mediated coral reef restoration. PloS one 8 (6): e64945. DOI: 10.1371/journal.pone.0064945.

Boury-Esnault, Rutzler K. 1997. Thesaurus of Sponge Morphology. Smithsonian Institute Press, Washington.

Brandt ME, Olinger LK, Chaves-Fonnegra A, Olson JB, Gochfeld DJ. 2019. Coral recruitment is impacted by the presence of a sponge community. Mar Biol 166 (4): 1-3. DOI: DOI: 10.1007/s00227-0193493-5.

Calcinai B, Bastari A, Bavestrello G, Bertolino M, Horcajadas SB, Pansini M, Makapedua DM, Cerrano C. 2017. Demosponge diversity from North Sulawesi, with the description of six new species. ZooKeys 680: 105-150. DOI: 10.3897/zookeys.680.12135

Chadwick NE, Morrow KM. 2011. Competition among sessile organisms on coral reefs. In: Dubinsky Z, Stambler N (eds). Coral Reefs: An Ecosystem in Transition. Springer, Dordrecht.

Chaves-Fonnegra A, Zea S. 2011. Coral colonization by the encrusting excavating Caribbean sponge Cliona delitrix. Mar Ecol 32 (2): 162173. DOI: 10.1111/j.1439-0485.2010.00416.x.

Cheng LS, de Voogd N, Tan KS. 2008. A Guide to Sponges of Singapore. Science Centre Singapore, Singapore.

de Goeij JM, Lesser MP, Pawlik JR. 2017. Nutrient fluxes and ecological functions of coral reef sponges in a changing ocean. In: Carballo JL, Bell JJ (eds). Climate Change, Ocean Acidification and Sponges (pp. 373-410). Springer, Cham.

de Voogd NJ. 2005. Indonesian Sponges: Biodiversity and Mariculture Potential. [Dissertation]. University of Amsterdam, Amsterdam. [Netherlands]

de Voogd NJ, Cleary DF, Hoeksema BW, Noor A, van Soest RW. 2006. Sponge beta diversity in the Spermonde Archipelago, SW Sulawesi, Indonesia. Mar Ecol Prog Ser 309: 131-142. DOI: 10.3354/meps309131.

de Voogd NJ, Cleary DF. 2008. An analysis of sponge diversity and distribution at three taxonomic levels in the Thousand Islands/Jakarta Bay reef complex, West-Java, Indonesia. Mar Ecol 29 (2): 205-215. DOI: 10.1111/j.1439-0485.2008.00238.x.

de Voogd NJ, Becking LE, Cleary DF. 2009. Sponge community composition in the Derawan islands, NE Kalimantan, Indonesia. Mar Ecol Prog Ser 396: 169-180. DOI: 10.3354/meps08349.

Eleftheriou A, McIntyre AD. 2005. Methods for the Study of Marine Benthos. Blackwell Science, United States.

George AM, Brodie J, Daniell J, Capper A, Jonker M. 2018. Can sponge morphologies act as environmental proxies to biophysical factors in the Great Barrier Reef, Australia? Ecol Ind 93: 1152-1162. DOI: 10.1016/j.ecolind.2018.06.016.

Giyanto, Iskandar BH, Soedharma D, Suharsono. 2010. Effisiensi dan akurasi pada proses analisis foto bawah air untuk menilai kondisi terumbu karang. Oseanologi Dan Limnologi di Indonesia 36 (1): 111130. [Indonesian] 
Giyanto, Mumby P, Dhewani N, Abrar M, Iswari MY. 2017. Indek Kesehatan Terumbu Karang Indonesia. Media Sains Nasional, Jakarta Utara. [Indonesian]

González-Rivero M, Yakob L, Mumby PJ. 2011. The role of sponge competition on coral reef alternative steady states. Ecol Mod 222 (11): 1847-1853. DOI: 10.1016/j.ecolmodel.2011.03.020.

Habibie MN, Permana DS, Suratno S. 2013. Simulasi gelombang ekstrim akibat swell di Indonesia menggunakan model Wavewatch-III. Jurnal Meteorologi dan Geofisika 14 (2): 99-108. DOI: 10.31172/jmg.v14i2.159. [Indonesian]

Hadi TA, Hafizt M, Hadiyanto H, Budiyanto A, Siringoringo RM. 2018. Shallow water sponges along the south coast of Java, Indonesia. Biodiversitas 19 (2): 485-493. DOI: 10.13057/biodiv/d190223

Hill MS. 1998. Spongivory on Caribbean reefs releases corals from competition with sponges. Oecologia 117 (1): 143-150. DOI: $10.1007 / \mathrm{s} 004420050642$

Hoeksema BW. 2007. Delineation of the Indo-Malayan centre of maximum marine biodiversity: The Coral Triangle. In: Renema W (eds). Biogeography, Time, and Place: Distributions, Barriers, and Islands. Springer, Dordrecht.

Hooper JN. 2000. Guide to Sponge Collection and Identification. Queensland Museum, Brisbane.

Kohler KE, Gill SM 2006. Coral Point Count with Excel extensions (CPCe): A visual basic program for the determination of coral and substrate coverage using random point count methodology. Comput Geosci 32 (9): 1259-1269. DOI: 10.1016/j.cageo.2005.11.009.

Komyakova V, Munday PL, Jones GP. 2013. Relative importance of coral cover, habitat complexity and diversity in determining the structure of reef fish communities. PloS One 8 (12): e83178. DOI: 10.1371/journal.pone.0083178.

Leichter JJ, Witman JD. 1997. Water flow over subtidal rock walls: Relation to distributions and growth rates of sessile suspension feeders in the Gulf of Maine Water flow and growth rates. J Exp Mar Biol Ecol 209 (1-2): 293-307. DOI: 10.1016/S0022-0981(96)02702-5.

Leinfelder RR, Seemann J, Heiss GA, Struck U. 2012. Could 'ecosystem atavisms' help reefs to adapt to the Anthropocene. Proceedings of the 12th International Coral Reef Symposium. Cairns, 9-13 July 2012. [Australia]

Madin JS, Baird AH, Bridge TC, Connolly SR, Zawada KJ, Dornelas M 2018. Cumulative effects of cyclones and bleaching on coral cover and species richness at Lizard Island. Mar Ecol Prog Ser 604: 263 268. DOI: $10.3354 / \mathrm{meps} 12735$.

Morrow C, Cárdenas P. 2015. Proposal for a revised classification of the Demospongiae (Porifera). Front Zool 12 (1): 1-27. DOI: 10.1186/s12983-015-0099-8

Octavina C, Asri ZH, Purnawan S, Ulfah M. 2018. Coral bleaching percentage in Krueng Raya Waters, Aceh Besar. Int J Sci Bas Appl 40 (2): 116-123.

Pile AJ, Young CM. 2006. The natural diet of a hexactinellid sponge: Benthic-pelagic coupling in a deepsea microbial food web. Deep-Sea Res I Oceanogr Res Pap 53 (7): 1148-1156. DOI: 10.1016/j.dsr.2006.03.008.

Powell AL, Hepburn LJ, Smith DJ, Bell JJ. 2010. Patterns of sponge abundance across a gradient of habitat quality in the Wakatobi Marine National Park, Indonesia. Open Mar Biol J 4 (1): 31-38. DOI: $10.2174 / 1874450801004010031$

Schönberg CH. 2008. A history of sponge erosion: from past myths and hypotheses to recent approaches. In: Wisshak M, Tapanila L (eds). Current developments in bioerosion. Springer, Berlin.
Selvin J, Ninawe AS, Seghal KG, Lipton AP. 2010. Sponge-microbial interactions: Ecological implications and bioprospecting avenues. Crit Rev Microbiol 36 (1): 82-90. DOI: 10.3109/10408410903397340.

Setiawan E, Muzaki FK, Nurhayati AP, Maulidina N. 2019. Record of shallow-water sponges in Simeulue Island, Aceh Province, Indonesia. Biodiversitas 20 (11): 3246-3257. DOI: 10.13057/biodiv/d201117.

Tun K, Chou LM, Low J, Yeemin T, Phongsuwan N, Setiasih N, Wilson J, Amri AY, Adzis KAA, Lane10 D. 2010. 1.1 A regional overview on the 2010 coral bleaching event in Southeast Asia. In: Ministry of the Environment, Japan. Status of Coral Reefs in East Asian Seas Region. Global Coral Reef Monitoring Network and Reef and Rainforest Research Center, Townsville.

Turicchia E, Hoeksema BW, Ponti M. 2018. The coral-killing sponge Chalinula nematifera as a common substrate generalist in Komodo National Park, Indonesia. Mar Biol Res 14 (8): 827-833. DOI: 10.1080/17451000.2018.1544420

Utami RT, Zamani NP, Maddupa HH. 2018. Molecular identification, abundance and distribution of the coral-killing sponge Terpios hoshinota in Bengkulu and Seribu Islands, Indonesia. Biodiversitas 19 (6): 2238-2246. DOI: 10.13057/biodiv/d190632

Van Colen C, De Backer A, Meulepas G, Van Der Wal D, Vincx M, Degraer S, Ysebaert T. 2010. Diversity, trait displacements and shifts in assemblage structure of tidal flat deposit feeders along a gradient of hydrodynamic stress. Mar Ecol Prog Ser 406: 79-89. DOI: 10.3354/meps08529.

Van Soest RW, Hooper JN. 2002. Order Haplosclerida Topsent, 1928. In: Systema Porifera. Springer, Boston, MA

Van Soest RW, Boury-Esnault N, Vacelet J, Dohrmann M, Erpenbeck D, De Voogd NJ, Santodomingo N, Vanhoorne B, Kelly M, Hooper JN. 2012. Global diversity of sponges (Porifera). PLoS one 7 (4): e35105. DOI: 10.1371/journal.pone.0035105.

Van Soest RWM, Boury-Esnault N, Hooper JNA, Rützler K, de Voogd NJ, Alvarez B, Hajdu E, Pisera AB, Manconi R, Schönberg C, Klautau M, Kelly M, Vacelet J, Dohrmann M, Díaz M-C, Cárdenas P, Carballo JL, Ríos P, Downey R, Morrow CC. 2021. World Porifera Database. http://www.marinespecies.org/porifera.

Vega C. 2002. Variación estacional de la bioactividad de la esponja Mycale ramulosa: Relación con procesos biológicos y factores ambientales. MSc thesis, Universidad Nacional Autónoma de México, Mazatlan, Sinaloa, Mexico.

Vinod K, George RM, Thomas PA, Manisseri MK, Shylaja G. 2014. Diversity and distribution of shallow water sponges (Porifera) in the coastal waters from Enayam to Kollam, south-west coast of India. Indian J Fish 61 (3): 52-57.

Wilkinson CR, Evans E. 1989. Sponge distribution across Davies Reef, Great Barrier Reef, relative to location, depth, and water movement. Coral Reefs 8 (1): 1-7. DOI: 10.1007/bf00304685.

Wulff JL. 1995. Effects of a hurricane on survival and orientation of large erect coral reef sponges. Coral Reefs 14 (1): 55-61. DOI: $10.1007 / \mathrm{bf00304073.}$

Wulff J. Regeneration of sponges in ecological context: is regeneration an integral part of life history and morphological strategies? 2010. Int Comp Biol 50 (4): 494-505. DOI: 10.1093/icb/icq100.

Yang J, Sun J, Lee OO, Wong YH, Qian PY. 2011. Phylogenetic diversity and community structure of sponge-associated bacteria from mangroves of the Caribbean Sea. Aquat Microb Ecol 62 (3): 231-240. DOI: $10.3354 / \mathrm{ame} 01473$. 